\title{
Impact of Decentralization and Regional Autonomy in the Context of Improving the Quality of Public Services Towards Good Governance
}

\author{
Fadjar Trisakti $^{1}$, Nico Djajasinga ${ }^{2}$ \\ ${ }^{1}$ UIN Sunan Gunung Djati Bandung, ${ }^{2}$ Politeknik Transportasi Darat, Indonesia-STTD \\ Email: fadjartrisakti@uinsgdd.ac.id
}

\begin{abstract}
To succeed in this global age, the emphasis of government must be on transforming public services through a decentralization paradigm. The decentralization model in Indonesia is the implementation of Law 22 the Year 1999 on Regional Autonomy, which provides that each Autonomous Zone has the authority to administer the interests of local government services on its initiative and based on its needs community services. The enactment of autonomy law gives a broader, more real, and responsible authority to run regional governments. The balancing of duties and tasks between the central government and the provincial governments ensures that each region must have ample income. The area must have enough sources of funding to take on the responsibility of administering the regional government. Regional autonomy gives freedom in formulating programs and submitting them to the central government. Public awareness of their right to get excellent public services is increasing. Therefore, reinventing the government's spirit must be transformed into public services, customer-oriented government, focusing on public services' needs and satisfaction, not on bureaucracy.
\end{abstract}

\section{Keywords: Decentralization, Regional Autonomy, Excellent Service, Reinventing Government}

\section{INTRODUCTION}

Public demands for a new paradigm of government administration based on bureaucratic professionalism are also getting sharper. Bureaucratic professionalism based on decentralization, transparency, accountability, and increased performance in providing services to the community (Tahir, 2014).

The foundation for introducing municipal autonomy is Law No. 23 of 2014, as amended by Law No. 32 of 2004 and Law No. 22 of 1999. Regional autonomy means the rights, powers, and responsibilities of the Autonomous Zone to administer and manage its own government and local people's needs in the framework of the United States of the Republic of Indonesia (Ristanty \& Handoyo, 2017). Autonomous regions, from now on referred to as regions, are legal community entities with geographical borders that are empowered to administer and handle government relations and the needs of the local community based on their initiatives, based on the desires of the citizens in the framework of the Unitary State of the Republic of Indonesia (Simandjuntak, 2015).
Decentralization must encourage public services that are closer to the people in need (Dwiyanto, 2018). The resulting public policies are expected to cut long bureaucratic ranges to avoid delays and a decrease in the quality of public services, which are the state's obligations to its citizens. The decentralization process's success can be measured by the better quality of public services (Sulila, 2015). The decentralization policy, which is only intended to replace the role of the central government in the regions without making changes to the social transactions that occur, it is very difficult to expect a positive effect from this public policy, therefore improving the quality of public services is a determinant factor in implementing decentralization policies (Sujarwoto, 2012).

Public Understanding of the legal basis or known public policies is one of the key factors in maintaining quality public service standards (Aarons et al., 2011). General Understanding of the formulation of public policies that regulate procedures and mechanisms for providing public services can be measured from the ease with which people understand these procedures, the readiness of the bureaucracy to give clarity to the public, transparent information about the intended 
public service standards and the behavior of public service officers towards the community in practice. provision of public services (Denhardt \& Denhardt, 2000). The policy formulation is, of course, at the stage of implementing public policies that have been previously determined.

Based on the above definition, the authors are interested in researching the delivery of public services, whether in line with the needs of the population, particularly following the implementation of decentralization or regional autonomy policies in Indonesia. Has the public policy system after the era of regional autonomy fulfilled all the principles set out in the principles of Good Governance? It is hoped that this study would enrich public policy information literature after the period of regional autonomy in Indonesia.

\section{METHOD}

This study using a qualitative design by conducting epistemological literature studies by examining public services after the implementation of regional autonomy or decentralization policies by seeing whether the government has been able to provide the City with reliable public services in compliance with the community's desires, following the procedure of decentralization within the Municipal Administration Jurisdiction. The use of a qualitative design that is supported by literature allows how to get that knowledge or, in other words, how is the process that provides the ability in the form of experience to be obtained through procedures, what things are considered to get correct knowledge, what is called truth, what are the criteria for truth and how, techniques, what means help to acquire proficiency which is called experience (Anggito \& Setiawan, 2018).

\section{RESULT AND DISCUSSION}

The governmental decentralization model in Indonesia is a regional autonomy model that, according to Law Number 22 of 1999, is the Autonomous Region's power to administer and control the interests of the local population based on its policies and the desires of the community in compliance with the legislation. Part of the restructuring of the state administration has brought about significant improvements in municipal governments' administrative and operational efficiency.

Regional control or the transfer of a substantial part of the jurisdiction from the national government to the regions will respond more quickly and effectively to community demands. The regional authority to make regional regulations will facilitate and improve the quality of government tasks in serving the community because the local government is the one who best knows the potential and conditions of the region and the needs of its people (Falah, 2015).

The key purpose of regional autonomy (decentralization) policy setting is to free the central government from undue pressures on domestic relations to read, recognize, adapt to and take advantage of other global developments. Around the same time, it is hoped that the central government would be better able to focus on formulating strategic national macro-policies. On the other hand, with the decentralization of the government powers passed to the provinces, the regions will face a major empowerment phase. Their capacity for initiative and innovation will be stimulated so that their ability to overcome multiple domestic challenges will be strengthened. Decentralization is a sign of confidence between the federal government and the regional governments. This, in itself, would preserve the legitimacy of the government and local citizens. Suppose they cannot do much in a centralized environment to overcome different challenges. In that case, they are forced into this autonomy system to find innovative solutions to the various problems (Fauzi, 2019).

With the enactment of the Regional Government Law and the Law on Fiscal Balance (as well as the Law on State Finance), the central government power is decentralized. This ensures that the government and the citizens of the regions are welcome to run their households safely. The central government no longer patronizes, let alone dominates. The central government's decentralization position is to oversee, track, supervise and review the implementation of regional autonomy. This task is not light, but it also does not overwhelm the environment. For this cause, in the sense of regional independence, an appropriate balance of clear vision and powerful central government leadership is required, with the flexibility to take the provincial government's initiative and creativity (Seymour \& Turner, 2002).

The Regional Government (Bureaucracy) as an actor in the decentralization process must be able and clever to carry out its main function, namely:

1. Regulation function, in this case regulating and protecting the citizens of the community so that they are always in an orderly and safe condition;

2. Services function, namely, providing services to the public in the areas of (a) administrative services such as administering ID cards, 
administering IMB, administering birth certificates, and others; (b) provision of infrastructure such as the provision of road infrastructure, lighting, clean water, and so on; (c) providing necessities such as education and health infrastructure. (Hadi, 2016).

The regulatory function is related to the political aspect as an effort to formulate state policies or the state's wishes. The service function is associated with the administrative part as something about implementing these policies.

Public services in regional autonomy will lure investors into investing in the regions. Excellent service, fast, precise, easy, cheap, and straightforward is needed by the business world. Service standards need to be compiled for each agency in the region, especially those in charge of providing services to the community. Regional regulations regarding local taxes permit need to be prepared carefully to avoid a flight of investor capital from one region to another (Juniawan, 2014).

Minimum Service Standards (MSS) compiled by local governments need to be socialized first to the public and business actors as stakeholders to obtain corrections, information, and evaluation of these standards. This is important considering that the community, including business people, are the target groups for implementing public services.

Socialization is a process of learning appropriate public policies so that public awareness, sensitivity, and participation in improving public services can emerge. People are no longer apathetic in responding to government services.

Community participation needs to be accommodated in a community association without waiting for more public service victims. The community needs to be fostered so that they can respond to local government public services with a communal philosophy that is Care, Share, and Fair, so that any problems in local government services can be detected and handled as early as possible Regional Regulations. (Perda) aspirational, accommodating, and transparent need to be formulated so that the public as informants, correctors, and evaluators from the mouth of the implementation of public services get more attention.

Practical experience in the field, expanding the range of service targets and service systems, is expected to foster local governments' creativity in improving public service quality to achieve satisfaction and public trust levels. The word creativity often enables a latent potential that raises policies in the regions that add to the community's burden, not necessarily guarantee an increase in service itself (Semil, 2018).

Service excellence or excellent service is an attitude or way of employees in serving customers satisfactorily (Barata, 2003). The importance of basing the essence of regional autonomy on the meaning of exceptional public service has prompted the government to issue several legal bases for implementing services to the community, namely the Decree of Minister of PAN Number. 81 of 1993 concerning Guidelines for Public Service Administration; Instruction of the Minister of Home Affairs Number. 25 of 1998 concerning One-Stop Licensing Services in Regions; Government Regulation (PP) Number 15 the Year 2000 concerning Government Authority and Provincial Authority as Autonomous Regions.

David Osborne (1993), with the concept of Reinventing Government (Entrepreneurial Bureaucracy), has changed the paradigm of public administration in which the operation of public organizations must base themselves on professionalism like business organizations. Efficiency, effectiveness, cheap, fast, quality by placing community satisfaction as a stakeholder as the main goal of public organizations.

According to Parasuraman et al. (1998), service quality is determined by five factors, namely: appearance (tangibles), reliability (reliability), responsiveness (responsiveness), assurance (assurance), and care (empathy). Parasuraman describes these five factors as follows:

1. Appearance (tangibles), namely the quality of service in the form of physical office facilities, computerized administration, waiting rooms, information places, and so on;

2. Reliability, namely the ability and reliability in providing reliable services;

3. Responsiveness, namely the ability to assist and provide services quickly and accurately and responsiveness to consumer desires;

4. Assurance, namely the ability, friendliness, and courtesy to ensure consumer confidence;

5. Concern (empathy), which is a firm but friendly attitude in providing services to consumers.

Local governments also need to pay attention to government bureaucratic theories related to public services, namely:

1. The concept of Pressure to be Competitive, meaning that if an era of government (in the regions) is very bad in public services, there is already a legal mechanism for replacing regional leaders; 
2. The concept of Publicity Sanction, meaning that the public has the right to know and understand which regional institutions or local governments have poor performance in public services so that the public can comparatively assess which local governments are bad or excellent in providing public services. Moreover, in terms of investment and licensing.

He further stated that local governments also need to pay attention to strategic public service concepts (Crompton \& MacKay, 1991), namely:

1. Perception of local governments in improving community welfare;

2. Minimum Service Standards (MSS) that are aspirational, accommodative, and transparent;

3. The normative control mechanism from the community on the performance of the services provided can be feedback for future service improvements;

4. Leadership in every public service institution in the regions;

5. Reforming the behavior of the local government bureaucracy in making policies and interacting with the implementation of public services;

6. Application of the idea of seamless government (short government structure) and proactive human resource management;

7. Community interest in the provision, correction and evaluation of facts on the delivery of public programs.

\section{CONCLUSION}

The concept of Reinventing Government (Entrepreneur Bureaucracy) has changed the paradigm of public administration in which the operation of public organizations must base themselves on professionalism like business organizations. Efficiency, effectiveness, cheap, fast, and quality by placing community satisfaction as a stakeholder as the main goal of public organizations.

Public awareness of their rights to receive exceptional public services has now increased, so it is necessary to transform the entrepreneurial spirit into the bureaucracy, one of which concerns the service quality sector, namely the principle of customeroriented (community) oriented government, meeting needs and satisfaction. A society, not the needs and happiness of the bureaucracy. As a public organization, local governments need to be in line with the entrepreneurial spirit in the bureaucracy, which changes the paradigm of public services to be more oriented towards the public's needs and satisfaction as customers and not the needs and satisfaction of bureaucrats. The regional government's success will be assessed and supported by the community, including business actors as stakeholders of the quality of its services. Judges who judge the good or bad quality of local government services is the people.

\section{REFERENCES}

1. Aarons, G. A., Hurlburt, M., \& Horwitz, S. M. (2011). Advancing A Conceptual Model Of Evidence-Based Practice Implementation In Public Service Sectors. Administration and Policy in Mental Health and Mental Health Services Research, 38(1), 4-23.

2. Anggito, A., \& Setiawan, J. (2018). Metodologi Penelitian Kualitatif. Jejak Publisher.

3. Barata, A. A. (2003). Dasar-Dasar Pelayanan Prima. Elex Media Komputindo.

4. Crompton, J. L., \& MacKay, K. J. (1991). Identifying Dimensions of Service Quality. Journal of Park and Recreation Administration, 9(3), 15-27.

5. Denhardt, R. B., \& Denhardt, J. V. (2000). The New Public Service: Serving Rather than Steering. Public Administration Review, 60(6), 549-559.

6. Dwiyanto, A. (2018). Administrasi Publik: Desentralisasi Kelembagaan dan Aparatur Sipil Negara. UGM PRESS.

7. Falah, R. G. (2015). Kedudukan, Tugas dan Wewenang Wakil Kepala Daerah dalam Pemerintahan Daerah Pasca Reformasi di Indonesia (Doctoral dissertation, Universitas Islam Indonesia).

8. Fauzi, A. (2019). Otonomi Daerah dalam Kerangka Mewujudkan Penyelenggaraan Pemerintahan Daerah yang Baik. Jurnal Spektrum Hukum, 16(1), 119-136.

9. Hadi, K. (2016). Korupsi Birokrasi Pelayanan Publik di Era Otonomi Daerah. Jurnal Penelitian Politik, 7(1), 20.

10. Hamid, A. A. (2011). Otonomi Daerah dan Kualitas Pelayanan Publik. Academica, 3(1).

11. Juniawan, M. R. (2014). Analisis Perbandingan Standar Operasional Prosedur (SOP) Pelayanan Perizinan pada Unit Pelayanan Terpadu dan Badan Pelayanan Perizinan Terpadu Satu Pintu Di Kota Samarinda. Jurnal Ilmu Pemerintahan, 2(2), 2795-2808. 
12. Osborne, D. (1993). Reinventing Government. Public Productivity \& Management Review, 349-356.

13. Parasuraman, A., Zeithaml, V. A., \& Berry, L. L. (1994). Reassessment of Expectations As A Comparison Standard in Measuring Service Quality: Implications for Further Research. Journal of Marketing, 58(1), 111-124.

14. Ristanti, Y. D., \& Handoyo, E. (2017). UndangUndang Otonomi Daerah dan Pembangunan Ekonomi Daerah. Jurnal RAK (Riset Akuntansi Keuangan), 2(1), 115-122.

15. Semil, N. (2018). Pelayanan Prima Instansi Pemerintah: Kajian Kritis pada Sistem Pelayanan Publik di Indonesia. Prenada Media.

16. Seymour, R., \& Turner, S. (2002). Otonomi Daerah: Indonesia's Decentralisation Experiment. New Zealand Journal of Asian Studies, 4, 33-51.

17. Simandjuntak, R. (2015). Sistem Desentralisasi Dalam Negara Kesatuan Republik Indonesia
Perspektif Yuridis Konstitusional. Journal de Jure, 7(1), 57-67.

18. Simanjuntak, B. A. (2017). Konsepku Mensukseskan Otonomi Daerah: Membangun Indonesia Berkeadilan Sosial-Ekonomi. Yayasan Pustaka Obor Indonesia.

19. Simanjuntak, B. A. (2018). Strategi dan Problem Sosial Politik Pemerintahan Otonomi Daerah Indonesia: Konsep Mensukseskan Otonomi Daerah. Yayasan Pustaka Obor Indonesia.

20. Sugiyono, P. (2005). Memahami Penelitian Kualitatif. Bandung: Alfabeta.

21. Sujarwoto, S. (2012). Political Decentralization and Local Public Services Performance in Indonesia. Journal of Public Administration and Governance, 2(3), 55-84.

22. Sulila, I. (2015). Implementasi Dimensi Layanan Publik dalam Konteks Otonomi Daerah. Deepublish.

23. Tahir, A. (2014). Kebijakan Publik dan Transparansi Penyelenggaraan Pemerintahan Daerah. Alfabeta. 